\title{
Perbankan Syariah Dan Konversi Bank Konvensional Menjadi Bank Syariah Ditinjau Dari Hukum Positif
}

\author{
Giffari Syarlas \\ Magister Ilmu Hukum, Universitas Indonesia \\ Email Korespondensi: syarlasg@gmail.com
}

\begin{abstract}
Abstrak. Upaya-upaya akselerasi perkembangan perbankan syariah tidak hanya dilakukan oleh Pemerintah dan Otoritas Jasa Keuangan sebagai regulator saja, tetapi juga perlu dukungan dari internal bank syariah, serta apresiasi positif masyarakat Indonesia, sehingga membuat bank konvensional tertarik untuk mengkonversi usaha banknya menjadi usaha secara syariah. Metodologi dalam tulisan ini bersifat yuridis normatif dengan tujuan untuk mengkaji idealitas konsep perkembangan perbankan di Indonesia, dimana bank yang beroperasi di Indonesia tidak hanya bank konvensional saja akan tetapi juga terdiri dari bank yang sudah menjalani prinsip syariah yang didasari dengan hukum-hukum Islam antara bank dan kegiatan lainnya. Simpulan dari tulisan ini adalah Konversi ditinjau dari hukum positif, yakni bahwa Bank umum Konvensional yang ingin mengubah kegiatan usahanya menjadi bank yang berdasarkan prinsip syariah harus memenuhi ketentuan yang terdapat pada Pasal 4 ayat (1) Peraturan Otoritas Jasa Keungan Nomor 64/POJK.03/2016 tentang Perubahan Kegiatan Usaha Bank Konvensional menjadi Bank Syariah, yaitu hanya dapat dilakukan dengan izin dari Otoritas Jasa Keuangan.
\end{abstract}

Kata Kunci: bank konvensional, bank syariah, kegiatan usaha, konversi, hukum positif.

Abstract. Efforts to accelerate the development of Sharia banking are not only carried out by the Government and the Financial Services Authority as regulators, but also need support from internal Sharia banks, as well as positive appreciation of the Indonesian people, thus making conventional banks interested in converting their bank business into sharia business. The methodology in this paper is normative juridical with the aim to examine the ideality of the concept of banking development in Indonesia, where banks operating in Indonesia are not only conventional banks but also consist of banks that have undergone sharia principles based on Islamic laws between banks and other activities. The conclusion of this paper is that conversion is reviewed from positive law, namely that Conventional commercial banks that want to turn their business activities into banks based on sharia principles must meet the provisions contained in Article 4 paragraph (1) of the Regulation of the Financial Services Authority No. 64/POJK.03/2016 concerning Changes in Business Activities of Conventional Banks into Sharia Banks, which can only be done with permission from the Financial Services Authority.

Keywords: conventional banks, sharia banks, business activities, conversion, positive law.

\section{PENDAHULUAN}

Pesatnya perkembangan syariah di Indonesia dipicu oleh lahirnya UndangUndang Nomor 10 Tahun 1998 tentang Perubahan atas Undang-Undang Nomor 7 Tahun 1992 tentang Perbankan yang memungkinkan perbankan menjalankan dual banking system. Undang-Undang tersebut menyatakan secara tegas bank boleh beroperasi berdasarkan prinisp syariah.
Undang-Undang Perbankan juga mengizinkan bank konvensional beroperasi berdasarkan prinsip syariah dengan membuka Islamic windows atau Unit Usaha Syariah ("UUS"). Dalam hal ini, Indonesia mengikuti langkah Malaysia yang telah menerapkan terlebih dahulu konsep dual banking system semenjak tahun 1983 dengan diberlakukannya Akta Perbankan Islam (Islamic Banking Act). Pasca perubahan Undang-Undang Perbankan 
tersebut, pertumbuhan perbankan syariah di Indonesia meningkat dengan signifikan karena bank bisa membuka Unit Usaha Syariah. Di samping itu, untuk meningkatkan pertumbuhan perbankan syariah, bank konvensional juga dibolehkan mengkonversi kegiatan usahanya berdasarkan prinsip syariah dengan syarat mendapatkan izin dari Otoritas Jasa Keuangan berdasarkan Peraturan Otoritas Jasa Keungan Nomor 64/POJK.03/2016 tentang Perubahan Kegiatan Usaha Bank Konvensional menjadi Bank Syariah.

Bank Konvensional yang menguasai pasar mulai melirik dan membuka unit usaha syariah. Prinsip Syariah yang dimaksud yaitu aturan perjanjian berdasarkan hukum Islam antara bank dan kegiatan lainnya yang dinyatakan sesuai syariah, antara lain pembiayaan berdasarkan prinsip bagi hasil (mudharabah), pembiayaan dengan prinsip penyertaan modal (musyakarah), prinsip jual beli barang dengan memperoleh keuntungan (murabahah), pembiayaan barang modal berdasarkan prinsip sewa murni tanpa pilihan (ijarah) atau adanya pilihan pemindahan kepemilikan barang yang disewa dari pihak bank oleh pihak lain (ijarah wa istiqna).

Kinerja dan kontribusi perbankan syariah yang cukup pesat dalam beberapa tahun terakhir ini membuktikan bahwa perbankan syariah memang sesuai dengan kebutuhan masyarakat dan zaman. Upaya-upaya akselerasi perkembangan perbankan syariah tidak hanya dilakukan oleh Pemerintah dan Otoritas Jasa Keuangan sebagai regulator saja, tetapi juga perlu dukungan dari internal bank syariah, serta apresiasi positif masyarakat Indonesia, sehingga membuat bank konvensional tertarik untuk mengkonversi usaha banknya menjadi usaha secara syariah.

Sejak diberlakukannya Undang-Undang Nomor 21 Tahun 2008 tentang Perbankan Syariah ("UU 21/2008), maka persoalan pengembangan Perbankan Syariah melalui mekanisme baru, yakni mekanisme akuisisi dan konversi Bank Konvensional menjadi Bank Syariah. Implementasinya dapat dilakukan melalui tiga pendekatan yakni:

1. Bank umum konvensional (BUK) yang telah memiliki UUS (unit usaha syariah), mengakuisisi bank yang relatif kecil kemudian mengkonversinya menjadi Bank Syariah dan melepaskan serta menggabungkan UUS dengan bank yang baru dikonversi tersebut.

2. BUK yang belum memiliki UUS, mengakuisisi bank yang relatif kecil dan mengkonversinya menjadi Bank Syariah.

3. BUK melakukan pelepasan (spin-off) UUS dan dijadikan Bank Umum Syariah ("BUS") tersendiri.

Adanya proses konversi bank dimaksud secara umum harus memperhatikan dan mengindahkan Undang-Undang Nomor 40 Tahun 2007 tentang Perseroan Terbatas dan peraturan pelaksanaannya, serta ketentuan khusus yang ada dalam peraturan perundangundangan di bidang perbankan. Proses konversi bank Konvensional menjadi bank Syariah secara teknis tidak dijumpai dalam Undang-Undang Nomor 10 Tahun 1998 Tentang Perbankan. Ketentuan mengenai konversi secara teknis dijumpai dalam Peraturan Otoritas Jasa Keungan Nomor 64/POJK.03/2016 tentang Perubahan Kegiatan Usaha Bank Konvensional menjadi Bank Syariah ("POJK 64/2016") yang intinya mengatakan bahwa bank hanya dapat mengubah kegiatan usahanya menjadi bank yang melaksanakan kegiatan usaha bedasarkan Prinsip Syariah dengan izin Otoritas Jasa Keuangan.

\section{Rumusan Masalah}

Berdasarkan fakta yang telah dipaparkan di atas, maka penulis tertarik untuk melakukan penulisan artikel ilmiah dengan rumusan masalah sebagai berikut:

1. Bagaimana perbankan syariah ditinjau dari Hukum Positif?

2. Bagaimana perubahan kegiatan usaha bank konvensional menjadi bank syariah (konversi) ditinjau dari Hukum Positif?

\section{Tujuan Dan Manfaat Penelitian}

1. Tujuan Penelitian

Penelitian ini bertujuan untuk mengetahui, menganalisis, dan memahami perkembangan peraturan perbankan syariah khususnya peraturan terkait perubahan kegiatan usaha bank 
konvensional menjadi bank syariah (konversi).

2. Manfaat Penelitian

Penelitian ini mempunyai manfaat teoritis dan praktis. Secara teoritis penelitian ini diharapkan memberikan kontribusi dalam perkembangan ilmu hukum, terutama bidang hukum ekonomi dan ilmu perundang-undangan. Sedangkan secara praktis, hasil penelitian ini dapat digunakan sebagai sumber kajian ilmu pengetahuan umumnya bagi masyarakat umum dan khusunya kepada akademisi.

\section{METODE PENELITIAN}

Penelitian ini masuk dalam kategori penelitian normatif, karena dalam penelitian normatif terutama menggunakan bahan-bahan kepustakaan sebagai sumber data penelitian atau disebut juga dengan library research (studi pustaka) metode yang digunakan untuk mengumpulkan data dari berbagai literatur. Penelitian ini bersifat analisis kualitatifdeskriptif bahwa penelitian ini termasuk lingkup penelitian yang menggambarkan, menelaah, menjelaskan secara tepat serta menganalisis peraturan perundang-undangan yang berkaitan dengan penelitian ini. Penelitian normatif digunakan untuk mengkaji idealitas konsep perkembangan perbankan di Indonesia, dimana bank yang beroperasi di Indonesia tidak hanya bank konvensional saja akan tetapi juga terdiri dari bank yang sudah menjalani prinsip syariah yang didasari dengan hukum-hukum Islam antara bank dan kegiatan lainnya.

Analisis data yang digunakan dalam penelitian ini mengunakan deskriptifkualitatif. Masalah atau fakta yang dipaparkan secara deskriptif, kemudian dianalisis guna memperoleh gambaran yang utuh tentang permasalahan-permasalahan yang diteliti, termasuk dengan melakukan analisi isi (contect analysis). Penelitian deskriptif kualitatif yaitu sebuah penelitian yang berusaha mengungkapkan keadaan yang bersifat alamiah secara holistik. Penelitian kualitatif bukan hanya menggambarkan variabel-variabel tunggal melainkan dapat mengungkapkan hubungan antara satu variabel dengan variabel yang lainnya.

\section{HASIL PENELITIAN DAN PEMBAHASAN}

1. Perbankan Syariah Ditinjau dari Hukum Positif

a. Pengertian Perbankan Syariah

Berdasarkan Pasal 1 angka 1 UU 21/2008, Perbankan Syariah adalah segala sesuatu yang menyangkut tentang Bank Syariah dan Unit Usaha Syariah, mencakup kelembagaan, kegiatan usaha, serta cara dan proses dalam melaksanakan kegiatan usahanya. Sedangkan Bank Syariah terdiri dari dau kata, yaitu Bank dan Syariah. Kata Bank bermakna suatu lembaga keuangan yang berfungsi sebagai perantara keuangan dari dua pihak yaitu pihak yang berkelebihan dana dan pihak yang kekurangan dana. Kata Syariah bermakna peraturan-peraturan atau hukum-hukum yang sesuai dengan Hukum Islam.

Berdasarkan Pasal 1 angka 7 UU 21/2008, Bank Syariah adalah Bank yang menjalankan kegiatan usahanya berdasarkan Prinsip Syariah dan menurut jenisnya terdiri atas Bank Umum Syariah dan Bank Pembiayaan Rakyat Syariah. Sementara itu, menurut Sutan Remy Shahdeini, Bank Syariah adalah lembaga yang berfungsi sebagai intermediasi yaitu menyalurkan dana dari masyarakat dan menyalurkan kembali dana-dana tersebut kepada masyarakat yang membutuhkan dalam bentuk pembiayaan tanpa berdasarkan prinsip bunga, melainkan berdasarkan Prinsip Syariah.

\section{b. Dasar Hukum Perbankan Syariah}

Pada tahun 1998, Undang-Undang Nomor 7 Tahun 1992 tentang Perbankan ("UU 7/1992) diubah menjadi UndangUndang Nomor 10 Tahun 1998 tentang Perbankan ("UU 10/1998") yang mengalami beberapa perubahan yang memberikan peluang yang lebih besar bagi perkembangan perbankan syariah di 
Indonesia. Berdasarkan undang-undang tersebut dapat disimpulkan bahwa sistem perbankan di Indonesia bertujuan untuk sebagai berikut:

1. Memenuhi kebutuhan jasa perbankan bagi masyarakat yang tidak menerima konsep bunga. Dengan ditetapkannya sistem perbankan konvensional (dual banking system), mobilitas dana masyarakat dapat dilakukan secara lebih luas, terutama dari segmen yang selama ini belum tersentuh oleh sistem perbankan konvensional yang menerapkan sistem bunga.

2. Membuka peluang pembiayaan bagi pengembangan usaha berdasarkan prinsip kemitraan. Dalam prinsip ini, konsep yang diterapkan adalah hubungan antar-investor yang harmonis (mutual investor relationship). Sementara dalam bank konvensional konsep yang diterapkan adalah hubungan debitur kreditur (debitor to creditor relationship).

3. Memenuhi kebutuhan akan produk dan jasa perbankan yang memiliki beberapa keunggulan komparatifberupa peniadaan pembebanan bunga yang berkesinambungan (perfectual interest effect) membatasi kegiatan spekulasi yang tidak produktif, pembiayaan ditujukan kepada usahausaha yang lebih memperhatikan unsur moral

Pemberlakuan UU 10/1998 ini merupakan momen perkembangan perbankan syariah di Indonesia. Undang-Undang tersebut memberikan kesempatan yang seluas-luasnya bagi masyarakat untuk mendirikan bank yang menyelenggarakan kegiatan usaha berdasarkan Prinsip Syariah, antara lain pemberian kesempatan kepada Bank Umum untuk membuka kantor cabangnya yang khusus melakukan kegiatan berdasarkan Prinsip Syariah. Landasan dan kepastian hukum yang kuat bagi para pelaku bisnis serta mayarakat, meliputi:
1. Pengaturan aspek kelembagaan dan kegiatan usaha dan bank Syariah sebagaimana yang diamanatkan dalam pasal 1 angka 3 UU 10/1998, bahwa Bank Umum adalah bank yang melaksanakan kegiatan usaha secara konvensional dan atau berdasarkan Prinsip Syariah yang dalam kegiatannya memberikan jasa dalam lalu lintas pembayaran. Pasal tersebut menjelaskan, bank umum dapat memilih untuk melakukan kegiatan usaha berdasarkan sistem Konvensional atau berdasarkan prinsip syariah atau melakukan kedua kegiatan tersebut. Dalam hal bank umum melakukan usaha berdasarkan syariah, maka kegiatan tersebut dilakukan dengan membukasatuan kerja yaitu Unit Usaha Syariah ("UUS")

2. Sedangkan, berdasarkan Pasal 1 angka 4 UU 10/1998, bahwa Bank Perkreditan Rakyat ("BPR") adalah bank yang melaksanakan kegiatan usaha secara konvensional atau berdasarkan Prinsip Syariah yang dalam kegiatannya tidak memberikan jasa dalam lalu lintas pembayaran. Pasal tersebut menjelaskan, BPR harus memilih kegiatan usaha salah satu dari keduanya, melakukan kegiatan usaha berdasarkan prinsip syariah saja atau berdasarkan sistem konvensional saja.

Namun demikian, pada periode UU 10/1998 ini juga dapat dilihat adanya beberapa permasalahan hukum yang masih harus diatur lebih lanjut dan pengaturan tersendiri yang perlu dipertimbangkan dalam regulasi perbankan nasional yang akan datang. Masalah-masalah tersebut antara lain sebagai berikut:

1. Bank Islam tunduk pada dua sistem hukum yang berbeda.

2. Eksistensi Dewan Pengawas Syariah.

3. Pengawas Bank Islam masih berdasarkan pendekatan konvensional.

4. Bank sentral memakai standar interest.

5. Belum memadainya peraturan pelaksana bank Islam

6. Hukum Perdata tetap menjadi acuan dalam dokumentasi dan legitimasi

UU 21/2008 telah mengatur mengenai penyelesaian sengketa perbankan syariah, 
yang diatur dalam Bab IX Pasal 55 ayat (1), ayat (2) dan ayat (3), sebagaimana dijelaskan sebagai berikut:

1. Penyelesaian sengketa Perbankan Syariah dilakukan oleh pengadilan dalam lingkungan Peradilan Agama,

2. Dalam hal para pihak telah memperjanjikan penyelesaian sengketa selain sebagaimana dimaksud pada ayat 1, penyelesaiaan sengketa dilakukan sesuai dengan isi Akad,

3. Penyelesaian sengketa sebagaimana dimaksud pada ayat 2 tidak boleh bertentangan dengan Prinsip Syariah.

Pengadilan yang berwenang menyelesaikan sengketa perbankan syariah adalah Pengadilan Agama. Semenjak tahun 2006, dengan diamendemennya UndangUndang Nomor 7 Tahun 1989 dengan UndangUndang Nomor 3 Tahun 2006 tentang Peradilan Agama ("UU 3/2006"), kewenangan Peradilan Agama diperluas. Di samping berwenang memeriksa, memutus dan menyelesaikan sengketa di tingkat pertama antara orang-orang yang beragama Islam di bidang perkawaninan, waris, wasiat, hibah, wakaf, zakat, infak, dan shadaqah, Pengadilan Agama juga berwenang untuk memeriksa, memutus, dan menyelesaikan sengketa di bidang ekonomi syariah Pasal 49 huruf i UU 3/2006. Dalam penjelasannya, yang dimaksud dengan "ekonomi syariah" adalah "perbuatan atau kegiatan usaha yang dilaksanakan menurut prinsip syariah, antara lain meliputi: (a) bank syariah; (b) lembaga keuangan mikro syariah; (c) asuransi syariah; (d) reasuransi syariah; (e) reksa dana syariah; (f) obligasi syariah dan surat berharga berjangka menengah syariah; (g) sekuritas syariah; (h) pembiayaan syariah; (i) pegadaian syariah; (j) dana pensiunan lembaga keuangan syariah; dan (k) bisnis syariah."

Pasal 55 ayat (1) sampai ayat (3) UU 21/2008 telah sejalan dengan Undang-Undang Nomor 3 Tahun 2006 tentang Peradilan Agama yang juga mengatur mengenai sanksisanksi terhadap pelanggaran yang dilakukan oleh pihak Perbankan Syariah, yakni sanksi Administrasi dan sanksi Pidana. Sanksi Administrasi diatur dalam Pasal 57 ayat (1),
(2). dan Pasal 58 ayat (1 dan 2) UU 21/2008. Sedangkan sanksi pidana diatur dalam Bab XI Ketentuan Pidana UU 21/2008 tentang Perbankan Syariah diatur dalam Pasal 59 sampai dengan Pasal 66. Sanksi-sanksi Administrasi dan sanksi yang terkait dengan Tindak Pidana Perbankan Syariah tersebut, tidak ada satupun yang mengatur tentang sanksi pelanggaran Tindak Pidana atau Perdata terhadap pihak Perbankan dengan pihak nasabahnya/mitranya, atau bank dengan bank, juga dengan Lembaga lainnya.

\section{Perubahan Kegiatan Usaha Bank} Konvensional menjadi Bank Syariah (Konversi) Ditinjau Dari Hukum Positif a. Pengertian Konversi

Pada dasarnya dalam Kamus Besar Bahasa Indonesia (KBBI) istilah "konversi" berarti: perubahan dari satu sistem pengetahuan ke sistem yang lain; perubahan pemilikan atas suatu benda, tanah, dan sebagainya; perubahan dari satu bentuk (rupa dan sebagainya) ke bentuk (rupa dan sebagainya) yang lain; proses perubahan dari satu bentuk atau format ke bentuk atau format lainya. Sehingga konversi dapat diartikan sebagai proses perubahan dari sistem atau jenis instrumen tertentu menjadi sistem atau instrumen lainnya.

Berdasarkan Penjelasan atas POJK 64/2016 bahwa "konversi" adalah "perubahan kegiatan usaha", sehingga dapat diartikan bahwa Konversi adalah Perubahan Kegiatan Usaha Bank Konvensional menjadi Bank Syariah. Perubahan Bank Konvensional menjadi Bank Syariah secara Konversi mengakibatkan perubahan secara menyeluruh.

\section{b. Dasar Hukum Konversi}

Seiring dengan perkembangan bank di Indonesia, telah bermunculan bank konvensional yang mengubah kegiatan usahanya menjadi bank syariah. Pendirian bank syariah ini tentunya berdasarkan prinsip Syariah. Berdasarkan Pasal 1 angka 7 dan 10 UU 21/2008, bahwa Bank Syariah 
adalah Bank yang menjalankan kegiatan usahanya berdasarkan Prinsip Syariah dan menurut jenisnya terdiri atas BUS dan Bank Pembiayaan Rakyat Syariah, dan Unit Usaha Syariah, yang selanjutnya disebut UUS, adalah unit kerja dari kantor pusat Bank Umum Konvensional yang berfungsi sebagai kantor induk dari kantor atau unit yang melaksanakan kegiatan usaha berdasarkan Prinsip Syariah, atau unit kerja di kantor cabang dari suatu Bank yang berkedudukan di luar negeri yang melaksanakan kegiatan usaha secara konvensional yang berfungsi sebagai kantor induk dari kantor cabang pembantu syariah dan/atau unit Syariah.

Pada awalnya ketentuan mengenai Perubahan Kegiatan Usaha Bank Konvensional Menjadi Bank Syariah (Konversi) diatur dalam Peraturan Bank Indonesia Nomor 2/27/PBI/2000 tentang Bank Umum ("PBI 2/27/PBI/2000”) bahwa berdasarkan BAB X Perubahan Kegiatan Usaha dan Pembukaan Kantor Cabang Syariah Pasal 45 ayat (1) berbunyi "Bank yang melakukan kegiatan usaha secara konvensional hanya dapat mengubah kegiatan usahanya menjadi Bank yang melakukan Kegiatan Usaha Berdasarkan Prinsip Syariah dengan izin dari Dewan Gubernur Bank Indonesia." Setelah itu ketentuan mengenai Bank Umum tersebut perlu disempurnakan untuk mendorong perkembangan jaringan kantor bank yang melakukan Kegiatan Usaha berdasarkan Prinsip Syariah, sehingga PBI 2/27/PBI/2000 dicabut dan digantikan dengan Peraturan Bank Indonesia Nomor 4/1/PBI/2002 tentang Perubahan Kegiatan Usaha Bank Umum Konvensional Menjadi Bank Umum Berdasarkan Prinsip Syariah dan Pembukaan Kantor Bank Berdasarkan Prinsip Syariah oleh Bank Umum Konvensional ("PBI
4//1/PBI2002"). Kemudian ketentuan tersebut perlu untuk dilakukan pengaturan kembali terhadap memenuhi kebutuhan masyarakat akan jasa pelayanan perbankan syariah yang semakin meningkat, diperlukan jaringan kantor bank yang melaksanakan kegiatan usaha berdasarkan prinsip syariah yang lebih luas dan mudah dijangkau sehingga PBI 4//1/PBI2002 dicabut dan digantikan dengan Peraturan Bank Indonesia Nomor 8/3/PBI/2006 tentang Perubahan Kegiatan Usaha Bank Umum Konvensional Menjadi Bank Umum Yang Melaksanakan Kegiatan Usaha Berdasarkan Prinsip Syariah Dan Pembukaan Kantor Bank Yang Melaksanakan Kegiatan Usaha Berdasarkan Prinsip Syariah Oleh Bank Umum Konvensional ("PBI 8/3/PBI/2006").

Pada tahun 2007 PBI 8/3/PBI/2006 mengalami perubahan yaitu diubah ke dalam Peraturan Bank Indonesia Nomor 9/7/PBI/2007 tentang Perubahan Atas Peraturan Bank Indonesia Nomor 8/3/PBI/2006 tentang Perubahan Kegiatan Usaha Bank Umum Konvensional Menjadi Bank Umum Yang Melaksanakan Kegiatan Usaha Berdasarkan Prinsip Syariah dan Pembukaan Kantor Bank Yang Melaksanakan Kegiatan Usaha Berdasarkan Prinsip Syariah Oleh Bank Umum Konvensional ("PBI 9/7/PBI/2007") dengan mengubah Pasal 1, Pasal 38, Pasal 5, dan menyisipkan Pasal 39 A, serta merubah frasa 'penyaluran dana' dengan 'pembiayaan'.

Pada tahun 2009 Peraturan Bank Indonesia Nomor 11/15/PBI/2009 tentang Perubahan Kegiatan Usaha Bank Konvensional Menjadi Bank Syariah mencabut kedua aturan diatas yaitu PBI 8/3/PBI/2006 dan PBI 9/7/PBI/2007 sehingga dinyatakan tidak berlaku lagi. Kemudian pada tahun 2011 pengaturan dan 
pengawasan perbankan di Indonesia yang awalnya oleh Bank Indonesia menjadi Perbankan Indonesia diatur dan diawasi oleh Otoritas Jasa Keuangan (“OJK”). Dengan beralihnya peraturan dan pengawasan perbankan di Indonesia kepada OJK maka pengaturan terkait Perubahan Kegiatan Usaha Bank Konvensional menjadi Bank Syariah (Konversi) diubah menjadi Peraturan Otoritas Jasa Keuangan Nomor 64/POJK.03/2016 tentang Perubahan Kegiatan Usaha Bank Umum Konvensional Menjadi Bank Umum Syariah beserta dengan aturan pelaksanaanya yang diatur dalam Surat Edaran Otoritas Jasa Keuangan Nomor 2/SEOJK.03/2017 tentang Perubahan Kegiatan Usaha Bank Umum Konvensional Menjadi Bank Umum Syariah.

Bank umum konvensional yang ingin mengubah kegiatan usahanya menjadi bank yang berdasarkan prinsip syariah harus memenuhi ketentuan yang terdapat pada Pasal 4 ayat (1) Peraturan Otoritas Jasa Keungan Nomor 64/POJK.03/2016 tentang Perubahan Kegiatan Usaha Bank Konvensional menjadi Bank Syariah, yaitu hanya dapat dilakukan dengan izin dari Otoritas Jasa Keuangan. Dengan mencantumkan Rencana perubahan kegiatan usaha Bank Konvensional menjadi Bank Syariah harus dicantumkan dalam rencana bisnis Bank Konvensional. Serta dengan mengikuti ketentuan pelaksanaan Konversi sesuai dengan Surat Edaran Otoritas Jasa Keuangan Nomor 2/SEOJK.03/2017 tentang Perubahan Kegiatan Usaha Bank Umum Konvensional Menjadi Bank Umum Syariah.

\section{c. Bentuk-bentuk Konversi}

Trend terbaru pembentukan bank syariah yang saat ini muncul adalah melalui akuisisi dan konversi bank konvensional menjadi bank syariah. Adapun implementasinya dapat dilakukan melalui tiga pendekatan yaitu sebagai berikut:

1. BUK yang telah memiliki UUS mengakuisisi bank yang relatif kecil kemudian mengkonversinya menjadi syariah dan melepaskan serta menggabungkan UUS-nya dengan bank yang baru dikonversi tersebut. Contohnya seperti: Bank Syariah Bukopin, BRI Syariah, Bank Victoria Syariah, dan Maybank Syariah yang sekarang berubah nama menjadi Bank Net Syariah.

2. BUK yang belum memiliki UUS, mengakuisisi bank yang relatif kecil dan mengkonversinya menjadi syariah. Contohnya seperti: Bank Syariah Mandiri berasal dari akuisisi Bank Susila Bakti; Bank Mega Syariah dari akuisisi Bank Umum Tugu; dan BCA Syariah melalui Bank Jasa Artha.

3. Dengan melakukan spin-off (pelepasan) UUS dan dijadikan Bank Umum Syariah tersendiri. Contohnya seperti: Bank Jabar Banten Syariah; dan Bank BNI Syariah.

Pelepasan adalah pelepasan usaha dari satu bank menjadi dua badan usaha atau lebih, sesuai dengan ketentuan peraturan perundang-undangan. Pelepasan sebagaimana telah disebutkan di atas dapat dilakukan secara sukarela atau menjadi sesuatu yang wajib bagi UUS bank konvensional yang telah memenuhi persyaratan tertentu. Proses yang dilaksanakan mengalami kendala, karena hingga saat ini belum ada peraturan operasional mengenai hal tersebut, baik dalam bentuk Peraturan Pemerintah sebagaimana diamanatkan oleh Undang-Undang Nomor 40 Tahun 2007 maupun Peraturan Bank Indonesia. Pelepasan (spin-off) yang merupakan kewajiban diatur dalam 
Ketentuan Peralihan Pasal 68 UU 21/2008, yakni:

- Dalam hal BUK memiliki UUS yang nilai asetnya telah mencapai paling sedikit 50\% (lima puluh persen) dari total nilai aset bank induknya atau 15 (lima belas) tahun sejak berlakunya Undang-Undang ini, maka BUK dimaksud wajib melakukan Pelepasan UUS tersebut menjadi BUS.

- Ketentuan lebih lanjut mengenai pelepasan dan sanksi bagi BUK yang tidak melakukan pelepasan sebagaimana dimaksud pada ayat (1) diatur dengan Peraturan Bank Indonesia.

\section{Simpulan}

Berdasarkan uraian hasil penelitian diatas, dapat ditarik simpulan sebagai berikut:

1. Perbankan di Indonesia mulai disempurkan dalam Undang-Undang Nomor 7 Tahun 1992 Tentang Perbankan sehingga perbankan Indonesia memiliki sikap tanggap terhadap perkembangan pembangunan nasional, sehingga peranannya dalam peningkatan taraf hidup rakyat banyak, pemerataan pembangunan dan hasil-hasilnya serta peningkatan pertumbuhan ekonomi dan stabilitas nasional dapat terwujud secara lebih nyata, akan tetapi peranan Bank menyelenggarakan kegiatan usaha berdasarkan Prinsip Syariah baru terealisasi pada tahun 1998 dengan munculnya Undang-Undang Nomor 10 Tahun 1998 Tentang Perubahan Atas Undang-Undang Nomor 7 Tahun 1992 Tentang Perbankan. Oleh karena itu, Undang-Undang ini memberikan kesempatan yang seluas-luasnya bagi masyarakat untuk mendirikan bank yang menyelenggarakan keegiatan usaha berdasarkan Prinsip Syariah. Setelah itu pada tahun 2008 muncul Undang-Undang Khusus terkait Perbankan Syariah yaitu Undang-Undang Nomor 21 Tahun 2008 Tentang Perbankan Syariah. UndangUndang ini menjamin kepastian hukum bagi stakeholders dan sekaligus memberikan keyakinan kepada masyarakat dalam menggunakan produk dan jasa Bank Syariah, dalam Undang-Undang Perbankan Syariah ini diatur jenis usaha, ketentuan pelaksanaan syariah, kelayakan usaha, penyaluran dana, dan larangan bagi Bank Syariah maupun UUS yang merupakan bagian dari Bank Umum Konvensional. Sementara itu, untuk memberikan keyakinan pada masyarakat yang masih meragukan kesyariahan operasional Perbankan Syariah selama ini, diatur pula kegiatan usaha yang tidak bertentangan dengan Prinsip Syariah meliputi kegiatan usaha yang tidak mengandung unsur-unsur riba, maisir, gharar, haram, dan zalim.

2. Pengaturan konversi Bank Konvensional menjadi Bank Syariah mengalami beberapa perubahan. Konversi ditinjau dari hukum positif, yakni bahwa Bank umum Konvensional yang ingin mengubah kegiatan usahanya menjadi bank yang berdasarkan prinsip syariah harus memenuhi ketentuan yang terdapat pada Pasal 4 ayat (1) Peraturan Otoritas Jasa Keungan Nomor 64/POJK.03/2016 tentang Perubahan Kegiatan Usaha Bank Konvensional menjadi Bank Syariah, yaitu hanya dapat dilakukan dengan izin dari Otoritas Jasa Keuangan. Dengan mencantumkan Rencana perubahan kegiatan usaha Bank Konvensional menjadi Bank Syariah harus dicantumkan dalam rencana bisnis Bank Konvensional. Serta dengan mengikuti ketentuan pelaksanaan Konversi sesuai dengan Surat Edaran Otoritas Jasa Keuangan Nomor 2/SEOJK.03/2017 tentang Perubahan Kegiatan Usaha Bank Umum Konvensional Menjadi Bank Umum Syariah.

\section{DAFTAR PUSTAKA}

Amirudin dan Zainal Asikin, (2004), Pengantar Metode Penelitian Hukum, Jakarta: PT Raja Grafindo Persada.

Ghofur, Anshori Abdul, (2010) Pembentukan Bank Syariah Melalui Akuisisi Dan 
Konversi: Pendekatan Hukum Positif dan Hukum Islam, Yogyakarta: UUI Press.

Ghofur, Anshori Abdul., (2018), Perbankan Syariah di Indonesia, Yogyakarta: UGM Press.

Indonesia, Perbankan, Undang-Undang Nomor 10 tahun 1998.

Indonesia, Perbankan Syariah, UndangUndang Nomor 21 tahun 2008.

Indonesia, Perubahan Kegiatan Usaha Bank Konvensional menjadi Bank Syariah, Peraturan Otoritas Jasa Keungan Nomor 64/POJK.03/2016.

Indonesia, Perubahan Kegiatan Usaha Bank Umum Konvensional Menjadi Bank Umum Syariah, Surat Edaran Otoritas Jasa Keuangan Nomor 2/SEOJK.03/2017.

Mervin K. Levis dan Latifa M. Algoud, (2001), Perbankan Syariah Prinsip, Praktek dan Prospek, Jakarta: Serambi Ilmu Semesta.

Kamus Besar Bahasa Indonesia, Konversi, diakses dari https://kbbi.kemdikbud.go.id/entri/ko nversi, tanggal 10 Januari 2020.

Karim, Adiwarman A., (2008), Perbankan Syariah 2008: Evaluasi, Trend, dan Proyeksi, Research \& Management Division Head, Jakarta: KARIM Business Consulting.

Khotibul Umam dan Veri Antoni., (2017), Corporate Action Pembentukan Bank Syariah (Akuisisi, Konversi, Spin Off), Jakarta: Gajah Mada University Press.

R. Saliman Abdul., (2005), Hukum Bisnis Untuk Perusahaan, Jakarta: Kencana Prenada Media Group.

Remy Sjahdeini, Sutan., (2007), Perbankan Islam, Cetakan ke-3, Jakarta: PT Pustaka Utama Grafiti

Soerjono Soekanto dan Sri Mamudji, (1995), Penelitian Hukum Normatif, Jakarta: Raja Grafindo Persada.

Sri Imaniyati Neni, (2010), Pengantar Hukum Perbankan di Indonesia, Bandung: Refika Aditama. 